\title{
Effects of Treated Municipal Wastewater on Soil Chemical Properties and Heavy Metal Uptake by Sorghum (Sorghum Bicolor L.)
}

\author{
Mohammad Galavi (Corresponding author), Abbas Jalali \& Mahmmod Ramroodi \\ Department of agronomy, collage of agriculture \\ University of Zabol, P.O.Box 98615-538, Zabol, Iran
}

Tel: 98-542-222-5077_E-mail: mgalavi@yahoo.com

Sayed Roholla Mousavi

Aligoudarz Payam e Noor University, Aligoudarz, Iran

Tel: 98-664-222-0093 E-mail: rr_mousavi@yahoo.com

Hadi Galavi

Department of civil, University Putra Malaysia, Serdang, Malaysia

Tel: 60-17-265-2966_E-mail: hadigalavi@gmail.com

\begin{abstract}
In order to investigate the effect of treated municipal wastewater on soil chemical properties and heavy metal uptake by sorghum an experiment was carried out in the Institute of Agriculture at Zabol University, Iran 2007 in a randomized complete block design with four replications. The treatments were managed for irrigation; with well water during entire period of growing season as control (T1); wastewater during the first half of growing season (T2); wastewater during the second half of growing season (T3); wastewater and well water alternately (T4) and wastewater during entire period of growing season (T5). The results have indicated that irrigation with wastewater lead to significant increase in N, P, K, Ca, Na, Mg, SAR, EC, O.C\% than control treatment ( $\mathrm{p} \leq 0.05)$. In addition, the increases of $\mathrm{Zn}, \mathrm{Fe}, \mathrm{Mo}$ in soil, and $\mathrm{Cu}, \mathrm{Fe}$ in sorghum plant were statistically significant in comparison with control treatment $(\mathrm{p} \leq 0.01)$. The highest transfer coefficient was observed for $\mathrm{Mo}$ and $\mathrm{Pb}(1.28$, 1.02), and the lowest for $\mathrm{Cu}(0.077)$ which highlight the high absorption power of sorghum toward these elements.
\end{abstract}

Keywords: Heavy metals accumulation, Municipal wastewater, Soil chemical properties, Sorghum

\section{Introduction}

In most arid and semiarid regions of the world, including the lands of Iran (above 80\%) water crisis is considered as one of the main problems on the path of sustainable agriculture. Due to water restrictions and increased water consumption using low quality water resources (wastewater) is considered as a solution to resolve agricultural water requirements which is pointed out as the largest consumption of water recently. In 1996 the total volume of urban and industrial wastewater produced in Iran was 36.3 billion cubic meters (1-BCM) that urban wastewater formed 5.2 units out of all, 5.4 units in the year of 2001 and it is forecasted about 7 BCM for 2011. Wastewater can have a positive effect on soil and eventually plant growth, due to being rich of organic matter and nutrients such as nitrogen, potassium and phosphorus (Ghanbari et al, 2007; Mohammad and Ayadi, 2004). (Note 1) Discharge of unpurified wastewater into the rivers will pollute and decrease water quality in the rivers and soil pollution occurs while that water is used for irrigation, consequently.

Recently, one of the issues that attracted the attention of researchers and environmentalists is wastewater chemicals and heavy metals especially those which can penetrate into soil, plant and finally food chain (Ashworth and Alloway, 2003). Heavy metals represent a portion of important environmental pollutants which causes pollution problems by increasing their use in products in recent decades. In spite of gradual accumulation of heavy metals in the soil, the stability of heavy metals in the environment will cause to pollution since they could not be decomposed like organic pollutants by biological or chemical processes (McBride, 1995). 
Propagation of heavy metals in biological food chain is one of the important issues of this behavior, as increasing the amount of several heavy metals in higher stages of food chain is many times more than initial levels (Al-Enezi et al., 2005). The storage of heavy metals severely threaten human health, but duo to their long half-life (e.g. 1460 days for lead and 200 days for cadmium), tendency for storing such elements is dramatic (Pescod, 1992). Sorghum crop is important to provide livestock forage and forage health has a direct effect on human health (Al-Jaloud et al., 1995). Considering the importance of animal health and human nutrition in developing sustainable agriculture, this study was conducted to evaluate the effect of different treatments of irrigation with wastewater on absorption and accumulation of some heavy metals and their possible contaminations in sorghum crop and soil.

\section{Materials and methods}

The study was conducted in the Agricultural Institute of Zabol University Sistan and Baluchistan Province, Iran $\left(30^{\circ} 55^{\prime} \mathrm{N}, 61^{\circ} 31^{\prime} \mathrm{E}\right)$. The region has an arid climate with $483 \mathrm{~m}$ altitude from sea level. Annual mean precipitation and temperature are $55 \mathrm{~mm}$ and $21.7^{\circ} \mathrm{C}$, respectively. During the 2007 growing season (120 Day), the experiment was conducted out in a randomized complete block design with four replications. The irrigation treatments were as well water in all growing stages as a first treatment control (T1); wastewater during the first half of growing period before flag leaf appear (T2); wastewater during the second half of growing period after flag leaf appear (T3); wastewater and well water alternately (T4), and wastewater during the whole growing period (T5). The chemical fertilizers, $1 / 2 \mathrm{~N}, \mathrm{P}$ and $\mathrm{K}$ were applied before sorghum sowing. Each plot was constructed in $3 \times 2.5$ meter with 1 meter distance between plots and 2 meter distances between replications. Sorghum was seeded by $25 \mathrm{~kg} \mathrm{ha}^{-1}, 20 \mathrm{~cm}$ row distance, $15 \mathrm{~cm}$ between plants and $3-5 \mathrm{~cm}$ planting depth. Seeds were planted manually using two seeds per hole in May 2007. The forage was harvested at soft dough stage of grain maturity in August 2007. In this study, electrical conductivity was measured by conductivity meter No $646 \mathrm{ohm}$; percentage of organic matter by burning method (Horwitz, 2005), total soil nitrogen by Kjeldahl method (Rusan et al., 2007), plant available phosphorus by Olsen method (Ghanbari et al., 2007) and plants Potassium by normal ammonium acetate method with flem photometer (Chang et al., 1997) were quantified. Besides, concentration of heavy metals in soil and plant was measured by Atomic absorption (Fonseca et al., 2005b). Metals transfer coefficient (TC) was calculated to determine the actual absorption of heavy metals by plants. Transfer coefficient consist a proportion of metal transfer from plant to metal concentration in soil (Al-Enezi et al., 2005). The results of well water and wastewater quality analysis are shown in table 1, and they have been compared by suggested standards of Iran environment conservation organization (E.C.O of Iran, 1999) and FAO water qualitative standard (Pescod, 1992). In consequence, available water was found suitable for irrigation, and evaluation of wastewater pollution (Table 1) described that magnitude of sulfate, $\mathrm{NO} 3, \mathrm{PO} 4, \mathrm{Ca}, \mathrm{Mg}$ and heavy metals concentrations were below the critical limits (E.C.O. of Iran, 1999). For evaluation of wastewater microbial pollution determined critical limits have been used (E.C.O. of Iran, 1999).

The possibility of soil pollution with continues use of wastewater is figured out by the higher concentration of Sodium, Chloride, Boron and Sulfate than optimum limits. Electrical conductivity (EC) and concentration of Sodium, Chloride and Boron were above optimum level which it may cause toxic outbreak in sensitive plants (Ensink et al., 2007). Owing to the high concentration of chloride, sprinkler irrigation system can not be admissible. Sodium absorption ratio $(\mathrm{SAR}=13)$ has been measured in wastewater to determine existing sodium's efficacy on soil penetration and structure. (Note 2) The expectation for soil sodification because of low salinity $(5>\mathrm{EC}>3 \mathrm{ds} / \mathrm{m}-1)$ at wastewater is low, in spite of that, some long term studies have shown that in this case also sodification might happen (Kiziloglu et al., 2007).

Data analysis was done by using SAS software. The ANOVA test was used to determine significant $(p \leq 0.05)$ treatment effect and Duncan Multiple Range Test to determine significant difference between individual means.

\section{Results and discussion}

\subsection{N, $P$ and $K$ concentration changes in soil}

Comparison of means showed that the concentration of $\mathrm{N}, \mathrm{P}$ and $\mathrm{K}$ were significantly affected by irrigation treatments, so that the highest and lowest value of total nitrogen was obtained by irrigation with wastewater in whole growing season and control treatments respectively $(\mathrm{p} \leq 0.05)$ (Table 2). Soil nitrogen increased by wastewater treatments because of plentiful urea and nitrogen in urban wastewater (Bernala et al., 2006; Fonseca et al., 2005a). Difference between wastewater treatments in first half and second half of plant growth showed that irrigation by well water in second half reduced nitrogen concentration in soil due to leaching. In addition, all the indicators aforesaid in table 2 are following such trend as well. Nitrogen, phosphorus and potassium concentration increased by irrigation with wastewater rather well water. It explains the importance of wastewater 
to supply these elements in the soil results from other studies had reported that total soil nitrogen increased under the influence of urban wastewater or wastewater sludge irrigation; and increase in potassium and phosphorus in the soil as a result of wastewater application (Monnett et al., 1996; Fuentes et al., 2002). In some cases wastewater application provides $\mathrm{N}, \mathrm{P}$ and $\mathrm{K}$ up to 4,8 and 10 times more than forage plants need (Rusan et al., 2007).

\subsection{Ca, Mg, CEC and O.C concentration changes (Note 3)}

Irrigation with wastewater increased total cations concentration of $\mathrm{Ca}$ and $\mathrm{Mg}$ and soil organic carbon (O.C \%), so that the most cations concentration of $\mathrm{Mg}, \mathrm{Ca}$ and $\mathrm{O} . \mathrm{C} \%$ were obtained in T4 and T5 (Table 2). Zhang et al., (2008) have reported the significant increase in percentage of organic matter and improvement in soil structure as a result of irrigation with wastewater. Fuentes et al., 2002 also have demonstrated similar results from irrigation with urban wastewater and wastewater sludge as manure.

\subsection{Na, SAR and EC Concentration changes}

The results showed that there were many differences between treatments on soil sodium concentrations, sodium absorption ratio (SAR) and electrical conductivity (EC). SAR increased in soil solution by wastewater irrigation as maximum value was observed in T4 and T5 (Table 2). Moreover, soil salinity level increased in all wastewater treatments in compare with control. The maximum soil salinity was obtained by wastewater irrigation during entire period of growing season. Electrical conductivity of soil solution in the control treatment increased from 2.9 to 4.52 (ds m-1). The presence of soluble salt, sodium, magnesium and calcium in the wastewater can increase soil electrical conductivity (Ghanbari et al., 2007; Mohammad and Mazahreh, 2003; Monnett et al., 1996). It should be noted that salt accumulation in deeper layers was more than the superficial layers due to leaching (Abu-Awwad., 1996).

\subsection{Heavy metals concentration in soil and plant}

Analysis of variance showed the significant effect of irrigation with wastewater treatments on accumulation rate of $\mathrm{Fe}, \mathrm{Zn}$ and $\mathrm{Mo}$ in soil (Table 3). In the wastewater irrigation treatments increased but the copper and lead enhancement were not significant in terms of statistics (Table 4). Concentration of copper and iron in plant was affected by irrigation treatments and increased significantly (Table 4). Zinc concentration in the soil was affected by irrigation treatments and the maximum rate was found in T4 and T5 (Table 4). It is pointed out by the analysis of wastewater organic matter that Zinc increased in soil due to decrease in soil $\mathrm{pH}$ (Chang et al., 1997). Soil copper concentration was not affected by irrigation treatments. Smith (1994) reported that the copper sediment of insoluble hydroxide, carbonate and organic complexes increased by increase in soil $\mathrm{pH}$. Thus, ability of copper absorption was higher in the lower $\mathrm{pH}$. In addition, Luo and Christie (1998) believe that in calcareous and high acidity soil, microelements absorption ability (such as copper) is low for plants and hence they have recommended organic fertilizers usage to increase these elements in soil.

Irrigation with wastewater led to create optimal conditions for copper uptake and increased absorption by the plant rather the control treatment. Organic matter increased by the use of wastewater in soil. Environmental factors such as temperature and light affect plants growth; these two factors effectively can increase copper absorption (Gregori et al., 2003). Concentration of iron in the soil is affected by increased wastewater irrigation. Increasing the amount of absorbable iron in the soil of arid regions is important because iron deficiency is considered as the most important problems of plant nutrition in such soil (Al-Enezi et al., 2005). Maximum iron concentration $(1.13 \mathrm{mg} / \mathrm{kg})$ was obtained in irrigation with wastewater in the whole growth period. Absorbable iron concentration in soil increased and soil $\mathrm{pH}$ decreased by increasing soil organic matters, which could be considered as a resultant of wastewater application. It is demonstrated by Lindsay (1992) that solubility of iron has increased 1000 times per each unit of soil $\mathrm{pH}$ decrease. In the present research, iron concentration increased significantly by wastewater treatments (Table 4). Furthermore, Feizi (2001) in a research on heavy metals accumulation in soil and corn which has been irrigated by wastewater for 8 years has reported significant increase for iron content of corn. Lead concentration in soil and plant was not affected by wastewater irrigation. Lead is one of the most important environmental pollutant elements and many researchers believe that alkaline soil can prevent the occurrence of lead toxicity (Ioannis and Prodromos, 2009; Smith, 1994). Molybdenum concentration in soil was under the influence of wastewater irrigation as it increased 26 percent more than control treatment at irrigation by wastewater for entire growing season. On the other hand, Molybdenum concentration enhancement in plant was not affected by wastewater irrigation significantly (Table 4). It seems that in addition to lack of molybdenum concentration in the soil, other factors such as $\mathrm{pH}$ and organic materials have reduced its absorption by plant (Ioannis and Prodromos, 2009). The highest cumulative absorption was observed at molybdenum and lead, and for cooper it was the lowest. In fact, mobility and biological availability 
of molybdenum in soil were more than other elements (Table 5). The results of transfer coefficient test for elements under study are given below, highest and lowest transfer coefficients are belong to $\mathrm{Mo}$ and $\mathrm{Cu}$, respectively: $(\mathrm{Mo}>\mathrm{Pb}>\mathrm{Zn}>\mathrm{Fe}>\mathrm{Cu}$ ).

It should be mentioned that transfer coefficients vary among the plant species (Kalavrouziotis et al., 2009).

\section{Conclusion}

Wastewater irrigation increased the percentage of organic matters, total nitrogen content of soil, $\mathrm{K}, \mathrm{P}, \mathrm{Ca}, \mathrm{Mg}, \mathrm{Na}$, EC and sodium absorption ratio (SAR) in soil solution than control unit. Considering the probability of soil salinity enhancement, specifically in the arid areas, it could be controlled by irrigation with well water and wastewater alternately. In the irrigation with wastewater in the first half of growing season, which nutrients could be used in the beginning of growth and by well water irrigation in the second half, soil salinity and nitrate accumulation in the soil would be lessened. Wastewater irrigation had no significant influence on heavy metals concentration in soil. Total amount of heavy metals in soil is not enough to predict their absorption by the plant, because in the study on complex systems like soil and plant pollution several factors should be taken into account such as soil, metals, plant species and type of vegetation. Irrigation with wastewater has shown significant increase in zinc, iron and molybdenum in soil and copper and iron in plant; however, the concentration of all elements in soil and plant were lower than toxicity threshold. Transfer coefficients of molybdenum and lead were high in sorghum. The absorption of these elements by plants must be reduced with proper management to prevent forage toxicity and consequently poisoning.

\section{References}

Abu-Awwad, A. M. (1996). Irrigation water management for onion trickle irrigated with saline drainage water. Dirasat, 23, 46-55

Al-Enezi, G., Hamodam, M. F., \& Fawzi, N. (2005). Heavy metals content of municipal wastewater and sludges in Kuwait. Journal of Environmental Science and Health, 39, 397- 407

Al-Jaloud, A. A., Hussain, G., Al-Saati, A. J., \& Karimulla, S. (1995). Effect of wastewater irrigation on mineral composition of corn and sorghum plants in a pot experiment. Journal of plant nutrition, 18, 1677-1692

Ashworth, D. J., \& Alloway, B. J. (2003). Soil mobility of sewage sludge-derived dissolved organic matter, copper, nickel and zinc. Environmental Pollution, 127, 137-144

Bernala, A. D., Ramosa, S. M. C., Tapiaa, N. T., Portugalb, V. O., Hernandezc, J. T. F., \& Dendoovena, L. (2006). Effects of tanneries wastewater on chemical and biological soil characteristics. Applied Soil Ecology, 33, 269-277

Chang, A. C., Hyun, H., \& Page, A. L. (1997). Cadmium uptake for Swiss chard grown on composted sewage sludge treated field plots: plateau or time bomb?. Journal of Environmental Quality, 26, 11-19

Ensink, J. H. J., Vanderhoek,W., Mara, D. D., \& Cairncross, S. (2007). Waste stabilization pond performance in Pakistan and its implications for wastewater use in agriculture. Urban Water Journal, 4, 261-267

Environmental Conservation Organization of Iran (E.C.O). (1999). Criteria and Standards of Environmental. Publication of environmental conservation organization. Summer1999.

Feizi, M. (2001). Effect of treated wastewater on accumulation of heavy metals in plant and soil. In: Ragab Ragab, Geof Pearce, Ju-Changkim, Saeed Nairizi, and Atef Hamdy. (Eds). 2001. 52 ${ }^{\text {nd }}$ ICID, International Workshop on Wastewater Reuse and Management, Seoul, Korea. 137-146

Fonseca, A. F., Melfi, A. J., \& Montes, C. R. (2005a). Maize growth and changes in soil fertility after irrigation with treated sewage effluent. I. Plant dry matter yield and soil nitrogen and phosphorus availability. Communications in Soil Science and Plant Analysis, 36, 1965-1981

Fonseca, A. F., Melfi, A. J., \& Montes, C. R. (2005b). Maize growth and changes in soil fertility after irrigation with treated sewage effluent. II. Soil acidity, exchangeable cations, and sulfur, boron and heavy metals availability. Communications in Soil Science and Plant Analysis, 36, 1983-2003

Fuentes, E. R., Constantino, C. L., Silva, E. E., \& Dendooven, L. (2002). Characteristics, and carbon and nitrogen dynamics in soil irrigated with wastewater for different lengths of time. Bioresource Technology, 85, $179-187$

Ghanbari, A., Abedikoupai, J., \& TaieSemiromi, J. (2007). Effect of municipal wastewater irrigation on yield and quality of wheat and some soil properties in sistan zone. Journal of Science and Technology Agricultural and Natural Recourse, 10, 59-74 
Gregori, I. D., Fuentens, I. E., Rojas, E. M., Pinochet, M. H., \& Gautier, H. M. P. (2003). Monitoring of copper, arsenic and antimony levels in agriculture soils impacted and non-impacted by mining activities, from three regions in Chile. Journal of Environmental Monit, 5, 287-295

Horwitz, W. (2005). Official methods of analysis of AOAC International Publishe: Gaithersburg, Md: AOAC International.

Ioannis, K. K, \& Prodromos, H. K. (2009). Distribution of elemental interactions in Brussels sprouts plants, under the treated municipal wastewater. Journal of Plant Interactions, 4, 219-231

Kalavrouziotis, I. K., Koukoulakis, P. H., Papadopoulos, A. H., \& Mehra, A. (2009). Heavy metal accumulation in Brussels sprouts after irrigation with treated municipal waste water. Journal of Plant Interactions, 4, 41-48

Kiziloglu, F. M., Turan, M., Sahin, U., Angin, I., Anapali, O., \& Okuroglu, M. (2007). Effects of wastewater irrigation on soil and cabbage-plant (brassica olerecea var. capitate) chemical properties. Journal of Plant Nutrition and Soil Science, 170, 166-172

Lindsay, W. L. (1992). Chemical Equilibrium in soil. John Wiley and Sons, New York.

Luo, Y. M., \& Christie, P. (1998). Bioavailability of copper and zinc in soil treated with alkaline stabilized sewage sludge. Journal of Environmental Quality, 27, 335-342

McBride, M. B. (1995). Toxic metal accumulation from agricultural use of sludge: Are the USEPA regulations protective. Journal of Environmental Quality, 24, 5-18

Mohammad, M. J., \& Mazahreh, N. (2003). Changes in soil fertility parameters in response to irrigation of forage crops with secondary treated wastewater, Comm. Soil Sci. Plant Anal, 34, 1281-1294

Mohammad, M. J., \& Ayadi, M. (2004). Forage yield and nutrient uptake as influenced by secondary treated wastewater. Journal of Plant Nutrition, 27, 351-364

Monnett, G. T., Reneau, R. B., \& Hagedorn, C. (1996). Evaluation of spray irrigation for on-site wastewater treatment and disposal on marginal soils. Water Environmental Research, 68, 11-18

Pescod, M. B. (1992). Wastewater treatment and use in agriculture-FAO irrigation and drainage. Paper 47. Tyne and Wear Professor of Environmental Control Engineering and Head, Department of Civil Engineering University of Newcastle-upon-Tyne Newcastle-upon-Tyne, $u k$. Food and agriculture organization of the United Nations Rome.

Rusan, M. J. M., Hinnawi, S., \& Rousan, L. (2007). Long term effect of wastewater irrigation of forage crops on soil and plant quality parameters. Desalination, 215, 143-152

Smith, S. R. (1994). Effect of soil pH on availability to crops of metals in sewage sludge created soils. I. Nickel, copper and zinc uptake and toxicity to ryegrass. Environmental Pollution, 85, 321-327

Zhang, Y. L., Dai, J. L., Wang, R. Q., \& Zhang, J. (2008). Effects of long-term sewage irrigation on agricultural soil microbial structural and functional characterizations in Shandong, China. European Journal of Soil Biology, 44, 84-91

Notes

Note 1. Billion Cubic Meter ( BCM )

Note 2. Sodium Absorption Ratio (SAR)

Note 3. Cation Exchange Capacity (CEC) 
Table 1. quality of well water and treated wastewater $\left(\mathrm{mg} \mathrm{L}^{-1}\right)$

\begin{tabular}{|c|c|c|c|c|c|c|}
\hline \multirow{2}{*}{ parameter } & \multirow{2}{*}{$\begin{array}{l}\text { Well } \\
\text { Water }\end{array}$} & \multirow{2}{*}{$\begin{array}{l}\text { Standard } \\
\text { limit }\end{array}$} & \multirow{2}{*}{ Wastewater } & \multirow{2}{*}{$\begin{array}{l}\text { Standard } \\
\text { limit }\end{array}$} & \multicolumn{2}{|c|}{$\begin{array}{l}\text { Standard limit of pollutants } \\
\text { in }\end{array}$} \\
\hline & & & & & $\begin{array}{l}\text { Agriculture } \\
\text { applications }\end{array}$ & $\begin{array}{l}\text { Water } \\
\text { resources }\end{array}$ \\
\hline $\mathrm{pH}$ & 7.8 & 7.6 & 8.2 & 7.6 & $6-8.5$ & $6-8.5$ \\
\hline $\mathrm{EC}(\mathrm{dsm}-1)$ & 2.04 & 2.61 & $4.5-5.5$ & 2.97 & - & - \\
\hline Calcium & 140 & 200 & 90 & - & - & 75 \\
\hline Magnesium & 100 & 29.5 & 85.2 & - & 100 & 100 \\
\hline Chloride & 6.4 & $<142$ & 999.7 & - & 600 & 600 \\
\hline Sulfate & 374.4 & 501.1 & 739.2 & - & 500 & 400 \\
\hline Nitrate & - & - & 13.2 & - & - & 50 \\
\hline Phosphate & - & - & 13.5 & 4.1 & - & 6 \\
\hline Boron & - & - & 3.3 & & & 2 \\
\hline Sodium & 253 & 899.30 & 915.4 & - & - & - \\
\hline Potassium & - & - & 22.62 & - & - & - \\
\hline Cupper & - & 0.002 & 0.006 & 0.2 & 0.2 & 1 \\
\hline Manganese & - & - & 0.039 & - & 1 & 1 \\
\hline Zinc & - & - & 0.017 & - & 2 & 2 \\
\hline Ferro & - & 0.11 & 0.2 & 0.33 & 3 & 3 \\
\hline $\begin{array}{l}\text { Total Coliform } \\
\text { (MPN/100ml) }\end{array}$ & - & - & 85 & - & 1000 & 1000 \\
\hline
\end{tabular}

Table 2. comparing the averages for soil chemical characteristic before and after experiment $(0-30 \mathrm{~cm})$

\begin{tabular}{|l|l|l|l|l|l|l|}
\hline \multirow{2}{*}{ Parameters } & \multicolumn{5}{l}{ Irrigation treatment } \\
\cline { 2 - 7 } & $\begin{array}{l}\text { Before of } \\
\text { experiment }\end{array}$ & T1 & T2 & T3 & T4 & T5 \\
\hline EC (dsm-1) & 2.90 & $2.20 \mathrm{e}^{1}$ & $2.80 \mathrm{~d}$ & $3.82 \mathrm{~b}$ & $3.40 \mathrm{c}$ & $4.52 \mathrm{a}$ \\
\hline $\begin{array}{l}\text { Total nitrogen } \\
(\%)\end{array}$ & 0.046 & $0.049 \mathrm{~d}$ & $0.050 \mathrm{c}$ & $0.051 \mathrm{c}$ & $0.062 \mathrm{~b}$ & $0.067 \mathrm{a}$ \\
\hline $\mathrm{P}(\mathrm{ppm})$ & 2.8 & $2.9 \mathrm{e}$ & $5.3 \mathrm{~d}$ & $5.9 \mathrm{c}$ & $9.4 \mathrm{~b}$ & $10.8 \mathrm{a}$ \\
\hline $\mathrm{K}(\mathrm{ppm})$ & 180 & $181 \mathrm{~d}$ & $182 \mathrm{~cd}$ & $183 \mathrm{c}$ & $187 \mathrm{~b}$ & $189 \mathrm{a}$ \\
\hline O.C (\%) & 0.262 & $0.303 \mathrm{c}$ & $0.364 \mathrm{~b}$ & $0.380 \mathrm{ab}$ & $0.402 \mathrm{a}$ & $0.403 \mathrm{a}$ \\
\hline $\begin{array}{l}\text { Ca and Mg total } \\
\text { cations (meq/lit) }\end{array}$ & 22.00 & $24.50 \mathrm{~d}$ & $25.25 \mathrm{c}$ & $26.15 \mathrm{~b}$ & $26.75 \mathrm{ab}$ & $27.90 \mathrm{a}$ \\
\hline Na (ppm) & 25.9 & $26.1 \mathrm{~d}$ & $29.2 \mathrm{c}$ & $32 \mathrm{~b}$ & $37.3 \mathrm{a}$ & $37.4 \mathrm{a}$ \\
\hline SAR & 9.4 & $8.3 \mathrm{c}$ & $8.67 \mathrm{c}$ & $9.8 \mathrm{~b}$ & $10.5 \mathrm{ab}$ & $11.9 \mathrm{a}$ \\
\hline CEC ( meq/lit $)$ & 4.30 & $4.16 \mathrm{~b}$ & $5.10 \mathrm{ab}$ & $5.20 \mathrm{ab}$ & $5.08 \mathrm{ab}$ & $5.40 \mathrm{a}$ \\
\hline
\end{tabular}

1 - Row means followed by the same letter are not significantly different at 0.05 probability level 
Table 3. ANOVA of the effect of irrigation treatments on heavy metals concentration in soil and sorghum crop

\begin{tabular}{|l|l|l|l|l|l|l|}
\hline & S.O.V & $\mathrm{Zn}$ & $\mathrm{Cu}$ & $\mathrm{Fe}$ & $\mathrm{Pb}$ & $\mathrm{Mo}$ \\
\hline \multirow{5}{*}{ Soil } & Replication & $0.006 \mathrm{~ns}^{1}$ & $0.00001 \mathrm{~ns}$ & $0.001 \mathrm{~ns}$ & $0.001 \mathrm{~ns}$ & $0.0001 \mathrm{~ns}$ \\
\cline { 2 - 7 } & Irrigation & $0.0680^{* *}$ & $0.0013 \mathrm{~ns}$ & $0.0610^{* *}$ & $0.0001 \mathrm{~ns}$ & $0.0001^{* *}$ \\
\cline { 2 - 7 } & error & 0.002 & 0.0001 & 0.002 & 0.001 & 0.0001 \\
\cline { 2 - 7 } & $\mathrm{CV}(\%)$ & 1.62 & 0.11 & 3.88 & 3.15 & 10.99 \\
\hline \multirow{5}{*}{ sorghum } & Replication & $0.000013 \mathrm{~ns}$ & $0.001 \mathrm{~ns}$ & $0.064 \mathrm{~ns}$ & $0.001 \mathrm{~ns}$ & $0.007 \mathrm{~ns}$ \\
\cline { 2 - 7 } & Irrigation & $0.0001 \mathrm{~ns}$ & $0.010^{* *}$ & $0.070^{* *}$ & $0.001 \mathrm{~ns}$ & $0.645^{* *}$ \\
\cline { 2 - 7 } & error & 0.00014 & 0.0001 & 0.054 & 0.002 & 0.013 \\
\cline { 2 - 7 } & $\mathrm{CV}(\%)$ & 0.90 & 5.04 & 4.32 & 3.93 & 3.51 \\
\hline
\end{tabular}

$\mathrm{ns}=$ non significant, $* *=\mathrm{p}<0.01$

Table 4. comparing the averages of effect of irrigation treatments on heavy metals concentration in soil and sorghum crop

\begin{tabular}{|l|l|l|l|l|l|l|}
\hline \multirow{4}{*}{ parameters } & \multicolumn{6}{l}{ Wastewater irrigation } \\
\cline { 2 - 7 } & & $\mathrm{T} 1$ & $\mathrm{~T} 2$ & $\mathrm{~T} 3$ & $\mathrm{~T} 4$ & $\mathrm{~T}$ \\
\hline \multirow{5}{*}{ Soil } & $\mathrm{Zn}$ & $2.471 \mathrm{c}^{1}$ & $2.643 \mathrm{~b}$ & $2.607 \mathrm{~b}$ & $2.855 \mathrm{a}$ & $2.810 \mathrm{a}$ \\
\cline { 2 - 7 } & $\mathrm{Cu}$ & 0.622 & 0.633 & 0.630 & 0.651 & 0.677 \\
\cline { 2 - 7 } & $\mathrm{Fe}$ & $0.80 \mathrm{~b}$ & $1.11 \mathrm{a}$ & $1.11 \mathrm{a}$ & $1.12 \mathrm{a}$ & $1.13 \mathrm{a}$ \\
\cline { 2 - 7 } & $\mathrm{Pb}$ & 0.946 & 0.972 & 0.967 & 0.967 & 0.977 \\
\cline { 2 - 7 } & $\mathrm{Mo}$ & $0.164 \mathrm{~b}$ & $0.200 \mathrm{a}$ & $0.196 \mathrm{a}$ & $0.201 \mathrm{a}$ & $0.208 \mathrm{a}$ \\
\hline \multirow{5}{*}{ Sorghum } & $\mathrm{Zn}$ & 0.422 & 0.431 & 0.430 & 0.433 & 0.432 \\
\cline { 2 - 7 } & $\mathrm{Cu}$ & $0.040 \mathrm{~b}$ & $0.054 \mathrm{a}$ & $0.053 \mathrm{a}$ & $0.052 \mathrm{a}$ & $0.051 \mathrm{a}$ \\
\cline { 2 - 7 } & $\mathrm{Fe}$ & $0.096 \mathrm{~b}$ & $0.119 \mathrm{a}$ & $0.123 \mathrm{a}$ & $0.111 \mathrm{ab}$ & $0.120 \mathrm{a}$ \\
\cline { 2 - 7 } & $\mathrm{Pb}$ & 0.96 & 1.00 & 0.99 & 0.99 & 1.00 \\
\cline { 2 - 7 } & $\mathrm{Mo}$ & 0.242 & 0.251 & 0.246 & 0.253 & 0.257 \\
\hline
\end{tabular}

1 - Row means followed by the same letter are not significantly different at 0.01 probability level

Table 5. Transfer coefficient (TC) from soil to sorghum

\begin{tabular}{|l|l|l|l|l|l|}
\hline Elements & $\mathrm{Zn}$ & $\mathrm{Cu}$ & $\mathrm{Fe}$ & $\mathrm{Pb}$ & Mo \\
\cline { 2 - 6 } $\mathrm{TC}$ & 0.164 & 0.077 & 0.107 & 1.02 & 1.28 \\
\hline
\end{tabular}

